\title{
KARAKTERISTIK TALI AGEL BERKITOSAN SEBAGAI BAHAN ALAT PENANGKAPAN IKAN
}

\author{
Characteristics of Agel Rope with Chitosan as Fishing Gear Materials \\ Oleh: \\ Didin Komarudin ${ }^{1 *}$, Mulyono S. Baskoro22, Diniah³, Bambang Murdiyanto4, \\ Pipih Suptijah ${ }^{5}$
1Program Studi Teknologi Perikanan Laut, Sekolah Pascasarjana, IPB University.didinkomarudin@apps.ipb.ac.id. 2Departemen Pemanfaatan Sumberdaya Perikanan, Fakultas Perikanan dan Ilmu Kelautan, IPB University. baskoro.mul@gmail.com.
${ }^{3}$ Departemen Pemanfaatan Sumberdaya Perikanan, Fakultas Perikanan dan Ilmu Kelautan, IPB University. diniahbs@gmail.com.
${ }^{4}$ Departemen Pemanfaatan Sumberdaya Perikanan, Fakultas Perikanan dan Ilmu Kelautan, IPB University. murdiyanto2001@yahoo.com.

5Departemen Teknologi Hasil Perairan, Fakultas Perikanan dan Ilmu Kelautan, IPB University. suptijah@yahoo.com.

* Korespondensi: didinkomarudin@apps.ipb.ac.id

Diterima: 19 Maret 2018; Disetujui: 18 Oktober 2019

\begin{abstract}
Agel ropes have lower mechanical properties (breaking strength and elongation) than synthetic fiber ropes. Chitosan coating is expected to improve the mechanical properties of agel ropes. The aims of this study are to investigate the effect of immersion in chitosan on the physical and mechanical properties of agel ropes, and to examine the breaking strength and elongation of coated agel ropes after being soaked in both freshwater and seawater. This experimental study was conducted at the Laboratory of Fishing Gear Technology, Department of Fisheries Resources Utilization IPB University, and Laboratory of Forest Product Engineering, Department of Forest Products IPB University. The experiment involved $3 \mathrm{~mm}$ in diameter of two agel ropes incorporating control rope and agel rope soaked in 1\% chitosan for 24 hours. The control rope was light brown, stiff, and rough, while the treated rope was darker, less stiff, and smoother. The breaking strength of control and treated rope was significantly different $(P<0.05)$, which in respect constitute $15.06 \mathrm{kgf}$ and $24.54 \mathrm{kgf}$. The elongation of both ropes were also significantly different $(P<0.05)$, making 10,56\% for control and $18,04 \%$ for treated rope. Breaking strength of the agel rope decreased by $50 \%$ after being immersed for 28 days.
\end{abstract}

Keywords: agel rope, chitosan, breaking strength, elongation

\section{ABSTRAK}

Tali agel memiliki kekuatan putus dan kemuluran yang rendah dibanding tali berbahan sintetis. Pelapisan kitosan sebagai penguat tali agel diharapkan dapat meningkatkan sifat mekanik tali agel. Penelitian ini bertujuan menentukan pengaruh perendaman kitosan terhadap sifat fisik dan mekanik tali agel, serta menentukan pengaruh perendaman pada air tawar dan air laut terhadap kekuatan putus dan kemulurannya. Penelitian ini dilakukan di Laboratorium Teknologi Alat Penangkapan Ikan, Departemen Pemanfaatan Sumberdaya Perikanan, Fakultas perikanan dan IImu Kelautan IPB University dan Laboratorium Keteknikan Hasil Hutan, Departemen Hasil Hutan Fahutan, Fakultas Kehutanan, IPB University. Metode penelitian yang digunakan adalah experimental laboratory. Tali 
agel yang digunakan berdiameter $3 \mathrm{~mm}$, terdiri atas tali agel kontrol dan tali agel yang direndam dalam kitosan $1 \%$ selama 24 jam. Hasil penelitian menunjukkan bahwa tali agel tanpa kitosan berwarna coklat terang, kaku dan agak kasar jika diraba. Tali agel berkitosan berwarna coklat tua, tidak begitu kaku, dan lebih halus jika diraba. Kekuatan putus tali agel berkitosan sebesar 24,54 kgf, lebih kuat secara signifikan dibandingkan tali agel tanpa kitosan yaitu sebesar 15,06 kgf $(P<0,05)$. Kemuluran tali agel berkitosan rata-rata sebesar $18,04 \%$, lebih besar secara signifikan dibandingkan kemuluran tali agel tanpa kitosan yaitu sebesar $10,56 \%(P<0,05)$. Kekuatan putus tali agel berkurang sebanyak $>50 \%$ setelah dilakukan perendaman selama 28 hari.

Kata kunci: tali agel, kitosan, kekuatan putus, kemuluran

\section{PENDAHULUAN}

Penggunaan bahan sintetis pada beberapa alat penangkapan ikan memiliki dampak negatif terhadap lingkungan. Material sintetis membutuhkan waktu untuk terurai puluhan hingga ratusan tahun (Good et al. 2010). Apabila suatu alat tangkap hilang atau dibuang ke laut, akan mengakibatkan fenomena ghost fishing. Alat tangkap yang hilang akan terus melakukan penangkapan hingga alat tersebut rusak. Estimasi jumlah alat tangkap yang hilang setiap tahunnya sebesar 640.000 ton (APEC 2004, Gilardi et al. 2010).

Bahan alat penangkapan ikan berupa serat alami mulai banyak diteliti kembali, guna mengatasi dampak buruk penggunaan bahan sintetis pada suatu alat tangkap. Bahan alami ini dapat dipasang pada bagian tertentu suatu alat penangkapan ikan, sehingga ketika alat tersebut hilang, dapat mengurangi fishing power (kemampuan menangkap)-nya. Beberapa penelitian yang mengkaji peluang penggunaan serat bahan alami sebagai bahan alat penangkapan ikan yaitu: kajian awal penggunaan serat rumput teki (Fimbristylis sp.), linggi (Penicum sp.), dan sianik (Carex sp.) sebagai bahan alat penangkapan ikan (Nofrizal et al. 2012), kajian pemanfaatan serat daun pandan (Pandanus artocapus) untuk bahan alat penangkapan ikan (Rachmah et al. 2015), perpaduan serat daun nanas (Ananas Comosus) dan kitosan sebagai material alat penangkapan ikan ramah lingkungan (Mainnah et al. 2016) dan lain sebagainya.

Salah satu bahan alami yang berpeluang dapat digunakan sebagai bahan alat penangkapan ikan adalah tali agel. Tali agel merupakan tali berbahan daun agel atau daun lontar. Menurut Fox (1996), produksi tali agel cukup tinggi, dikarenakan pohon lontar cukup banyak di beberapa wilayah di Indonesia, seperti di Jawa Timur dan Jawa Tengah bagian timur, Madura, Bali, Nusa Tenggara Barat, Nusa Tenggara Timur, dan Sulawesi.
Tali agel yang terbuat dari serat alami, memiliki kekuatan putus dan kemuluran yang lebih rendah jika dibandingkan dengan tali yang terbuat dari serat sintetis. Selain itu, tali agel juga mudah rusak karena proses pembusukan oleh bakteri. Hal ini mengakibatkan umur teknis tali ini relatif rendah. Oleh karena itu, diperlukan penelitian untuk meningkatkan sifat mekanik tali agel agar dapat digunakan sebagai salah satu bahan alat penangkapan ikan saat ini.

Pada penelitian ini, kitosan digunakan sebagai bahan rendaman pada tali agel. Tujuannya untuk meningkatkan kekuatan putus dan kemuluran (sifat mekanik) tali, serta mengurangi dampak negatif terhadap lingkungan. Menurut Kumar et al. (2011), kitosan memiliki sifat yang tidak larut dalam air, memiliki ketahan kimia yang cukup baik, dan dapat terdegradasi. Kitosan juga dapat menyerap racun, sehingga dapat menetralisir sebagian kecil racun yang ada di dasar perairan.

Penelitian ini bertujuan untuk menentukan pengaruh perendaman kitosan terhadap sifat fisik dan mekanik tali agel, serta pengaruh perendaman pada media air tawar dan air laut selama periode waktu tertentu, terhadap kekuatan putus dan kemulurannya.

\section{METODE}

Penelitian dilaksanakan di Laboratorium Teknologi Alat Penangkapan Ikan, Departemen Pemanfaatan Sumberdaya Perikanan, Fakultas Perkanan dan IImu Kelautan, IPB University dan Laboratorium Rekayasa dan Desain Bangunan Kayu, Departemen Hasil Hutan, Fakultas Kehutanan, IPB University. Metode penelitian yang digunakan adalah experimental laboratory. Tali agel yang digunakan berdiameter rata-rata 3 $\mathrm{mm}$, terdiri atas tali agel kontrol dan tali agel perlakuan.

Penelitian diawali dengan merendam tali agel perlakuan dalam larutan kitosan $1 \%$ selama 24 jam (Gambar 1). Konsentrasi 1\% digunakan atas dasar penelitian pendahuluan yang menun- 
jukkan bahwa kitosan 1\% dapat melapisi tali dengan baik dan tidak membuat tali menjadi kaku. Selanjutnya tali agel kontrol dan perlakukan diukur diameternya. Pengukuran diameter dilakukan pada 3 titik tali, yaitu ujung $1(\mathrm{~A})$, tengah (T), dan ujung 2 (B) (Gambar 2). Pengukuran diameter tali dilakukan dengan cara melilitkan tali pada sebatang pensil, kemudian tebal lilitannya diukur. Diameter tali diperoleh dengan cara membagi tebal lilitan dengan jumlah lilitan (Gambar 3) (Prado dan Dremiere 1990).

Tahap selanjutnya adalah merendam tali pada media air laut dan air tawar. Perendaman tali dilakukan untuk melihat pengaruh perendaman pada durasi waktu tertentu terhadap kekuatan putus dan kemuluran tali. Waktu perendaman yang diamati adalah durasi perendaman tali selama 1, 2, 3, 4, 5, 14, 21, dan 28 hari.

Karakteristik yang diamati adalah sifat fisik dan mekanik tali agel. Sifat fisik yang diamati adalah warna, kekakuan dan kesan raba. Sifat mekanik yang diamati adalah kekuatan putus dan kemuluran. Menurut Fadhari (2015), kekuatan putus adalah kekuatan maksimal yang diperlukan untuk membuat putusnya bahan dalam su- atu uji yang menggunakan ketegangan. Kekuatan putus biasanya ditetapkan dalam satuan kilogram gaya (kgf). Adapun kemuluran adalah penambahan panjang tali maksimum pada saat tali tersebut putus. Pengukuran kekuatan putus dan kemuluran tali dilakukan menggunakan universal testing machine (UTM) merk INSTRON tipe 5989, dengan load cell berkapasitas $400 \mathrm{kN}$. Standar uji tarik dilakukan berdasarkan SNI ISO 1805: 2010 tentang "Alat penangkapan ikan berbahan jaring: penentuan gaya putus simpul dan benang jaring". Jumlah sampel tali pada setiap perlakuannya masing-masing sebanyak 50 sampel. Panjang setiap sampel yang dibuat sebesar $350 \mathrm{~mm}$, dengan area tali yang diuji sepanjang $250 \mathrm{~mm}$. Pengait atau penjepit pada mesin uji tarik yang digunakan, dikondisikan agar tidak terjadi slip ketika pengujian berlangsung. Ilustrasi pemasangan contoh uji pada penjepit dapat dilihat pada Gambar 4.

Sifat fisik yang diamati adalah warna, kekakuan dan kesan raba dianalisis secara deskriptif. Adapun perbedaan kekuatan putus dan kemuluran dianalisis menggunakan analysis of varians (ANOVA) Rancangan Acak Lengkap (RAL) satu faktor (Matjik dan Sumertajaya 2000).

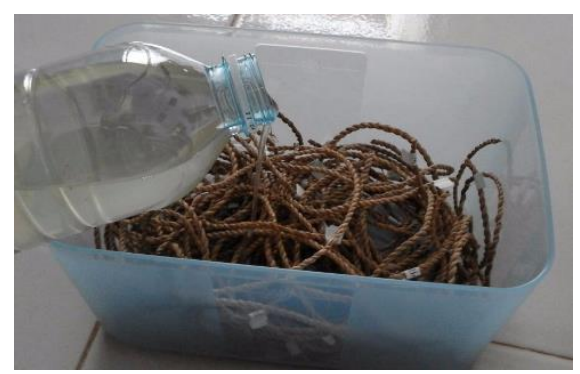

Gambar 1 Proses perendaman tali agel pada kitosan 1\%

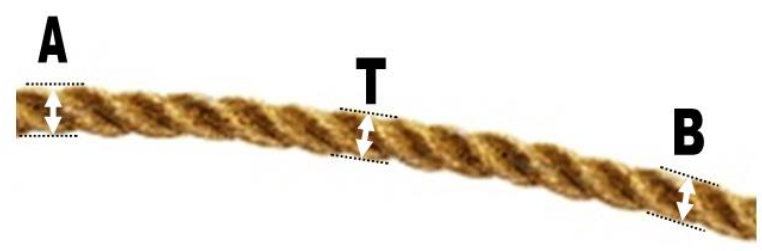

Gambar 2 Posisi pengukuran tali

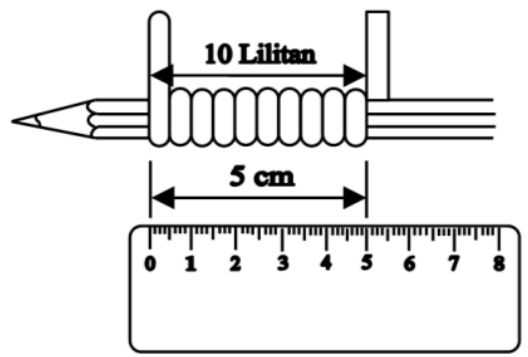

Gambar 3 Cara pengukuran diameter tali 

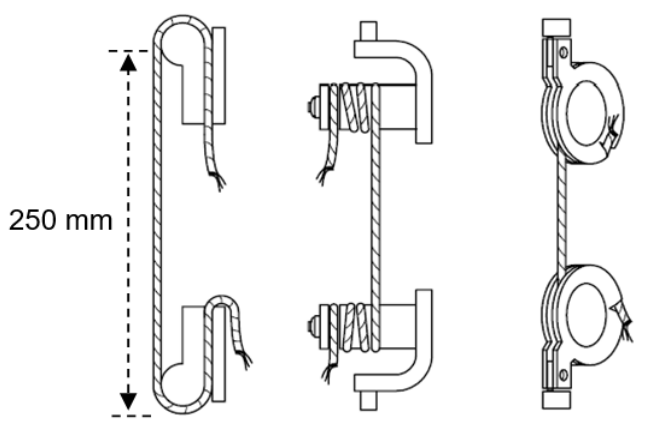

Sumber: SNI ISO 1805: 2010

Gambar 4 llustrasi pemasangan contoh uji pada mesin uji

\section{HASIL DAN PEMBAHASAN Sifat Fisik}

Hasil penelitian menunjukkan bahwa tali agel tanpa kitosan memiliki warna cokelat terang. Hal ini merupakan warna alamiah daun lontar yang menjadi bahan tali agel setelah dikeringkan. Daun lontar yang digunakan sebagai bahan baku pembuatan tali agel semula berwarna hijau dan kekuningan. Selanjutnya daun tersebut diraut dan dibiarkan mengering hingga warnanya kecokelatan (Widiastuti 2009; Fox 1996). Permukaan tali agel tanpa kitosan bertekstur kasar dan kaku. Hal ini dikarenakan daun agel memiliki kerapatan daging yang tinggi dan kadar air yang relatif rendah, terutama jika dalam keadaan kering. Oleh karena itu, tekstur daun agel sedikit kaku (Widiastuti 2009).

Tali agel yang berkitosan berwarna cokelat tua, tekstur permukaan tali lebih halus dan tidak terlalu kaku. Selain itu, permukaan tali juga sedikit mengkilat. Hal ini karena larutan kitosan meresap pada pori-pori tali agel kemudiana mengering, sehingga membuat warna tali menjadi lebih gelap. Larutan kitosan yang telah mengering dan melapisi permukaan tali mengakibatkan permukaan tali menjadi halus dan agak mengkilat. Kitosan yang telah dibentuk menjadi membran, memiliki tekstrur permukaan yang halus dan licin (Nisa 2005). Tali agel tanpa kitosan dan berkitosan tidak dapat dilihat pada Gambar 5.
Perendaman tali agel pada larutan kitosan memberikan pengaruh terhadap berat dan diameter tali. Tali agel berkitosan memiliki diameter dan berat yang lebih besar dibandingkan tali agel tanpa kitosan. Hal ini dikarenakan kitosan masuk ke dalam pori-pori tali dan melapisi permukaan tali. Hal ini dapat terjadi karena partikel kitosan sangat kecil, bahkan bisa dibuat hingga berukuran nano (Suptijah et al. 2011). Secara statistik berat dan diameter tali agel berkitosan dan tanpa kitosan berbeda nyata $(P<0,05)$. Rata-rata berat tali agel berkitosan sebesar 1,01 $\mathrm{g}$, sedangkan tali tanpa kitosan sebesar 0,95 g. Sementara itu, rata-rata diameter tali agel bekitosan sebesar $3,09 \mathrm{~mm}$, sedangkan tali agel tanpa kitosan sebesar 2,61 mm.

\section{Sifat Mekanik}

Kekuatan putus tali agel tanpa kitosan dan berkitosan berbeda nyata secara statistik ( $P$ $<0,05)$. Kekuatan putus rata-rata tali agel berkitosan sebesar 24,54 kgf, kekuatan putus tersebut lebih besar dibandingkan dengan tali agel tanpa kitosan yaitu sebesar 15,06 kgf. Kemuluran tali agel berkitosan dan tanpa kitosan juga berbeda nyata secara statistik $(P<0,05)$. Ratarata kemuluran tali agel berkitosan sebesar $18,04 \%$, sedangkan tali agel tanpa kitosan hanya memiliki kemuluran $10,56 \%$. Secara lebih jelas kekuatan putus dan kemuluran tali agel berkitosan dan tanpa kitosan, dapat dilihat pada Gambar 6 dan 7.
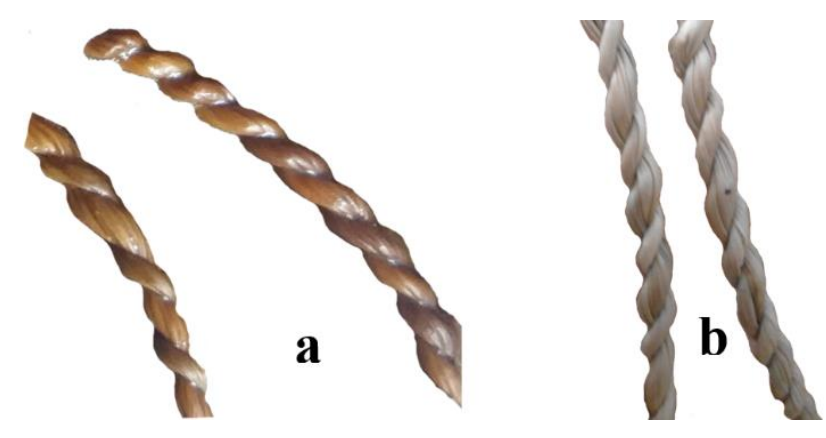

Gambar 5 Tali agel a) berkitosan, b) tanpa kitosan 


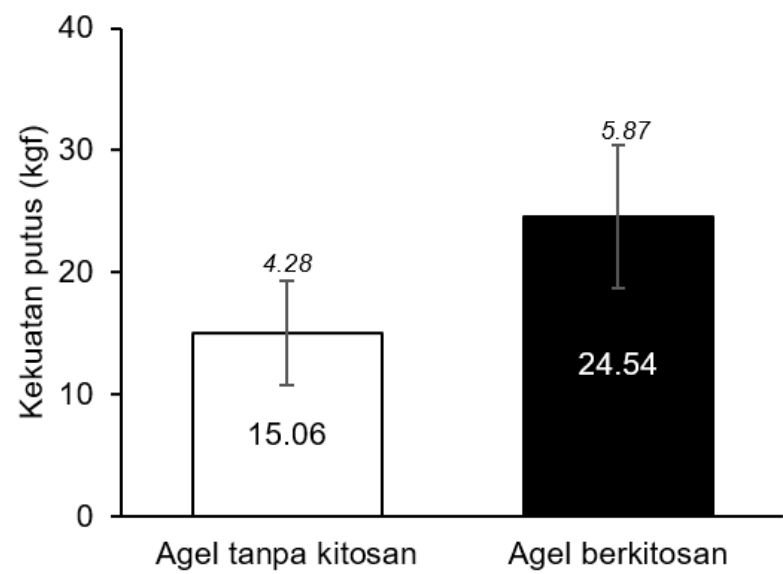

Gambar 6 Kekuatan putus tali agel tanpa kitosan dan berkitosan

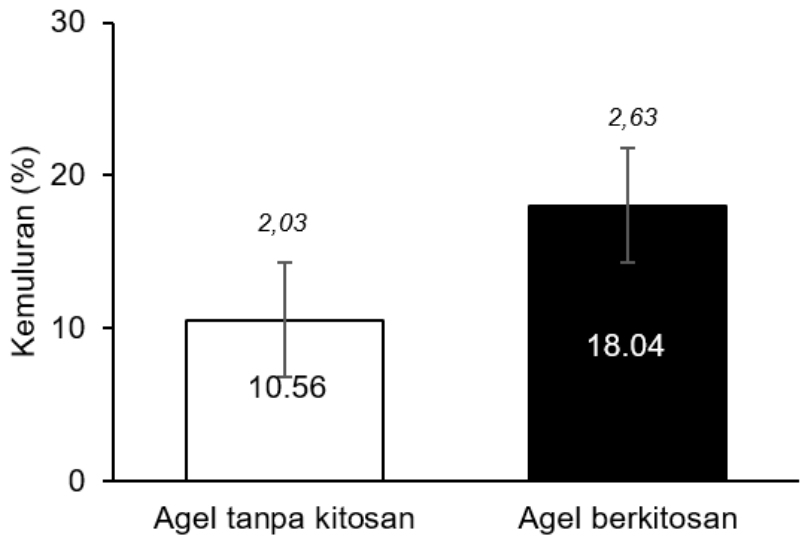

Gambar 7 Kemuluran tali agel tanpa kitosan dan berkitosan

Berdasarkan hasil pengamatan, tali agel yang telah direndam pada kitosan memiliki peningkatan kekuatan putus hinga 62,94\% dibanding tali agel tanpa kitosan. Hal ini karena kitosan dapat mengisi pori-pori tali dan terjadi ikatan antara kitosan dan serat tali. Ikatan antara kitosan dan serat tali dapat terjadi, karena kitosan memiliki struktur kimia yang mirip dengan serat selulosa yang ada pada tumbuhan (Yadaf dan Bhise 2004 diacu dalam Hardjito 2006). Selanjutnya Katili et al. (2013) dan Selpiana et al. (2016) menyatakan bahwa ikatan hidrogen pada kitosan memberikan kekuatan terhadap uji tarik. Semakin tinggi komposisi kitosan pada suatu film maka kekuatan tariknya akan semakin kuat. Selain itu, kemuluran tali agel yang dilapisi kitosan mengalami peningkatan sebesar $70,74 \%$ dibandingan dengan tali agel yang tidak dilapisi kitosan. Tali agel berkitosan memiliki rata-rata penambahan kemuluran sebesar 18,68 mm.

\section{Pengaruh Perendaman Tali terhadap Kekuatan Putus}

Perendaman tali pada media air tawar dan air laut mempengaruhi kekuatan putusnya.
Kekuatan putus tali agel tanpa kitosan pada awal pengujian kekuatan putus, rata-rata sebesar 22,19 kgf. Selanjutnya, kekuatan putusnya cenderung menurun dari hari ke hari, hingga pada hari perendaman ke 28 penurunan kekuatan putusnya melebihi $50 \%$ dari kekuatan putus awal. Kekuatan putus hari ke 28 sebesar 12, 39 kgf untuk perendaman pada media air laut dan 12,38 kgf pada media perendaman air tawar (Gambar 8).

Kekuatan putus tali agel berkitosan yang direndam pada media air tawar dan air laut pada saat awal pengujian rata-rata sebesar $26.07 \mathrm{kgf}$. Kekuatan putus pada hari berikutnya, cenderung mengalami penurunan. Kekuatan putus pada perendaman hari pertama hingga hari ke 4 cenderung menurun tajam. Namun kekuatan putus pada perendaman hari ke 4 hingga ke 14 cenderung konstan. Selanjutnya penurunan tajam terjadi pada waktu perendaman hari ke 14 hingga hari ke 28. Pada hari ke 28, kekuatan putus agel yang direndam pada air laut dan air tawar masing-masing sebesar 12,55 kgf dan 11,34 kgf. Secara lebih jelas kekuatan putus tali agel yang dilapisi kitosan, pada perendaman 
hari ke 1 hingga hari ke 28 dapat dilihat pada Gambar 9.

Secara umum, kekuatan putus tali agel berkitosan lebih tinggi dibandingkan dibanding tali agel tanpa kitosan, baik yang direndam pada media air laut maupun air tawar. Kondisi ini disebabkan karena kitosan pada tali dapat menghambat pembusukan yang sebabkan oleh bakteri-bakteri pembusuk. Berdasarkan penelitian yang dilakukan Tsai et al. (2000); Suptijah et al. (2008); Liu et al. (2006); Rafaat (2008); Herliana (2010), kitosan dapat berperan sebagai anti bakteri. Secara kasat mata, air perendaman tali agel tanpa kitosan kondisinya lebih keruh dibandingkan air rendaman tali agel berkitosan. Hal ini diduga disebabkan karena aktivitas bakteri pembusuk pada air rendaman tali agel tanpa kitosan lebih tinggi (Gambar 10).

Berdasarkan Gambar 8 dan 9, kekuatan putus tali agel yang direndam pada air laut cenderung lebih tinggi dibandingkan tali yang direndam pada air tawar. Hal ini terjadi baik pada tali yang dilapisi kitosan maupun yang tidak, sehingga proses pembusukan tali pada media air laut relatif lebih lambat dibanding air tawar. Hal ini disebabkan karena kandungan garam pada air laut ikut menghambat perkembang biakan bakteri. Garam memiliki tekanan osmotik yang tinggi sehingga menyebabkan plasmolisis pada dinding sel bakteri (Sanger 2010).

Kekuatan putus tali agel pada kondisi kering relatif lebih tinggi dibandingkan pada kondisi basah. Walau demikian, selisihnya tidak terlalu besar. Selisi kekuatan putus tali agel tanpa kitosan dalam kondisi kering dan basah sebesar 1,8 kgf. Baik pada media perendaman air tawar maupun air laut. Sementara itu, selisih kekuatan putus tali agel berkitosan kering dan basah, sebesar 1,79 kgf. Perbedaan kekuatan putus tali pada kondisi basah dan kering umum terjadi, baik pada tali atau benang berbahan serat alami maupun sintetis (Prado dan Dremiere 1990). Nilai gaya putus benang nylon basahnya akan berkurang paling tidak $10 \%$ dari yang kering, serta akan kembali pulih saat telah kering (McKenna et al. 2004 diacu dalam Qoniurrochmatulloh 2015). Jika tali tersebut akan dijadikan sebagai bahan pembuat alat penangkapan ikan, maka kekuatan putus dalam kondisi basah merupakan salah satu faktor penting yang harus dipertimbangkan.

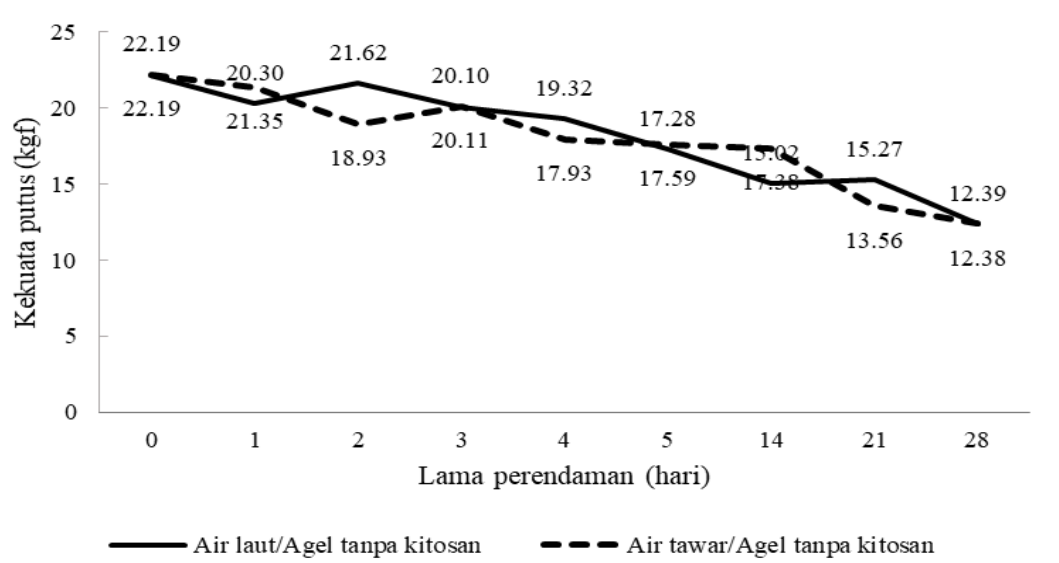

Gambar 8 Kekuatan putus tali agel tanpa kitosan pada media perendaman air tawar dan air laut

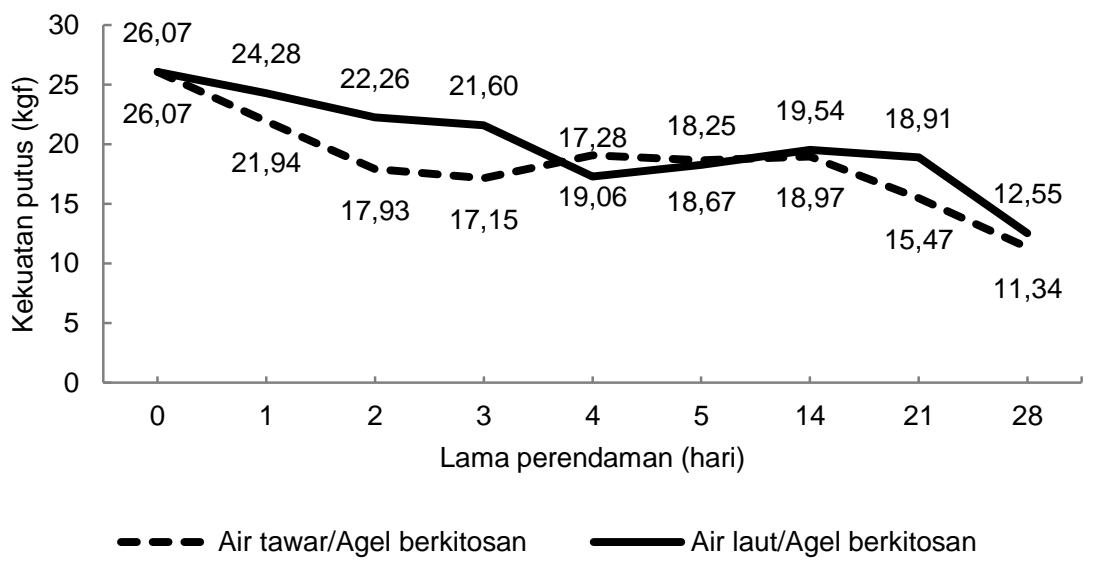

Gambar 9 Kekuatan putus tali agel berkitosan pada media perendaman air tawar dan air laut 


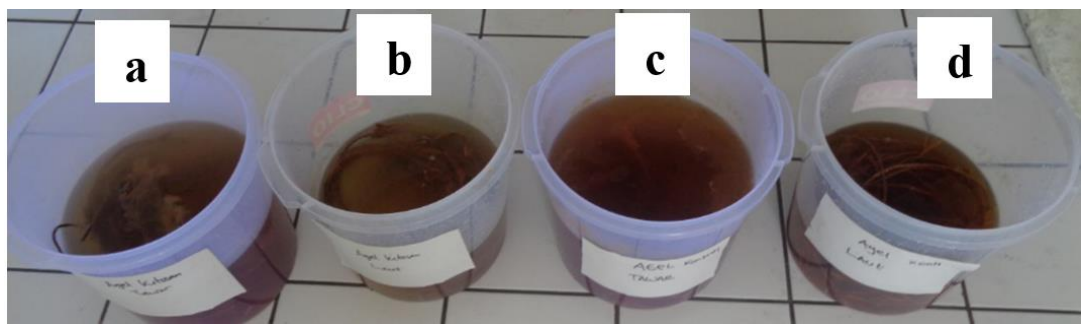

Keterangat:

Tali agel berkitosan/air tawar

Tali agel berkitosan/air laut

Tali agel tanpa kitosan/air

tawar

Tali agel tanpa kitosan/air

tawar

Gambar 10 Kondisi perendaman tali agel pada air laut dan air tawar

\section{Pengaruh Perendaman Tali terhadap Kemuluran}

Kemuluran tali agel yang dihasilkan mengalami fluktuasi dari hari ke hari. Walau demikian, kemulurannya secara keseluruhan cenderung konstan. Penurunan yang terjadi secara umum tidak signifikan. Artinya, tali agel memiliki kelebihan bahwa pada perlakukan perendaman, walaupun kekuatan putus menurun, namun kemulurannya relatif stabil. Berdasarkan uji statistik, nilai kemuluran tali agel yang dilapisi kitosan dan yang tidak, pada media perendaman air tawar dan air asin tidak berbeda nyata $(P>0,05)$.

Gambar 11 dan 12 menunjukkan kemuluran tali agel berkitosan dan tanpa kitosan yang direndam selama 28 hari, yang mana kemulurannya mengalami fluktuatif. Hal ini dikarena jenis serat tali agel merupakan staple fiber, atau seratserat penyusunnya berupa serat putus-putus (discontinous fiber). Ikatan-ikatan antar serat yang satu dengan yang lain pada umumnya tidak sepenuhnya seragam.. Terlebih lagi, saat ini tali agel masih diproduksi secara manual (hand made) (Antana et al. 2016).

\section{Peluang Penggunaan Tali Agel pada Alat Penangkapan Ikan}

Kekuatan putus tali agel dan kemuluran yang dihasilkan cukup baik. Kekuatan putus yang dimiliki cukup tinggi untuk ukuran tali yang berbahan serat alami. Kemuluran yang dimilikinya pun stabil, pada periode perendaman hingga 28 hari. Menurut Safitri et al. (2006), benang jaring yang baik untuk digunakan sebagai bahan alat penangkapan ikan adalah yang memiliki nilai kekuatan putus yang tinggi dan kemuluran yang rendah. Kemuluran yang tinggi dapat menyebabkan perubahan bentuk dan ukuran mata jaring sehingga ikan yang tertangkap akan mudah lepas. Walau demikian, benang yang memiliki kemuluran tinggi juga diperlukan bagi alat tangkap yang menangkap ikan dengan cara terpuntal.

Tali agel bisa digunakan sebagai pengikat antara tali ris bawah dengan tali pemberat pada gillnet dasar (Gambar 13). Saat ini, tali pengikat yang biasa digunakan nelayan berbahan polyamide $(P A)$ dengan diameter $0,5 \mathrm{~mm}$. Kekuatan putus PA tersebut dalam kondisi kering sebesar $12 \mathrm{kgf}$ dan pada kondisi basah sebesar 6,5 kgf (Prado dan Dremiere 1990). Nelayan biasanya melilitkan tali PA dengan jumlah yang banyak, agar tali tidak mudah putus. Kekuatan putus pada tali agel berkitosan menjadi 24,54 kgf, membuat tali agel berkitosan tersebut sangat berpeluang untuk digunakan sebagai salah satu bahan penyusun gillnet dasar tersebut.

Penggunaan tali agel sebagai pengikat antar tali ris bawah dengan tali pemberat diharapkan dapat mengurangi dampak buruk ghost fishing jika jaring gillnet dasar tersebut hilang.

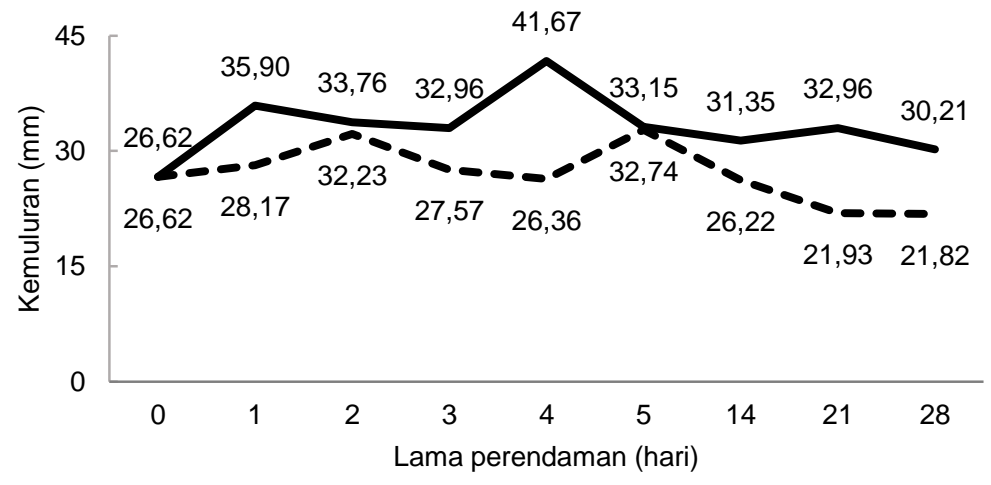

Air laut/Agel tanpa kitosan - - Air tawar/Agel tanpa kitosan

Gambar 11 Kemuluran tali agel tanpa kitosan pada media perendaman air tawar dan air laut 


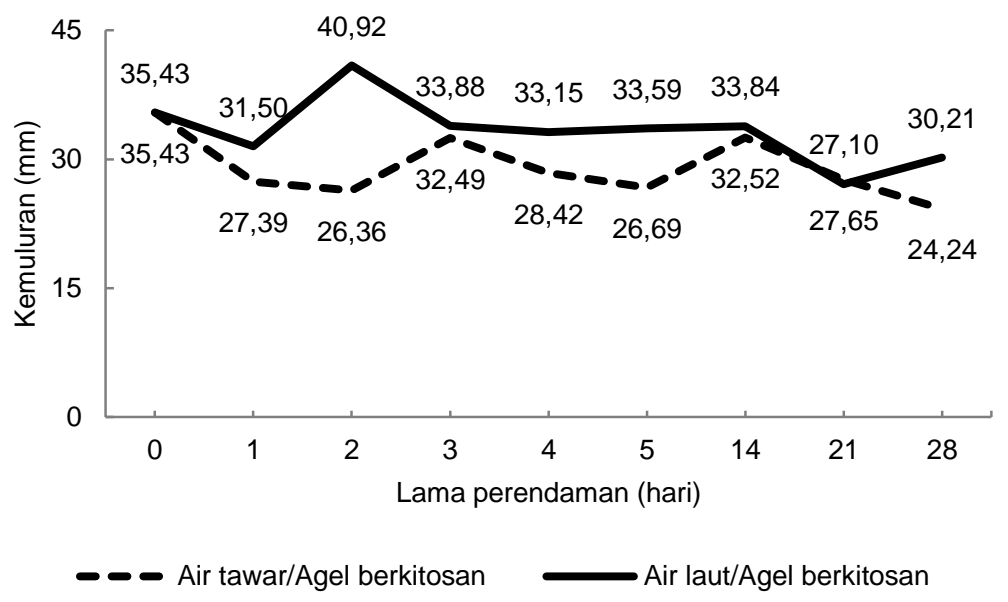

Gambar 12 Kemuluran tali agel berkitosan pada media perendaman air tawar dan air laut

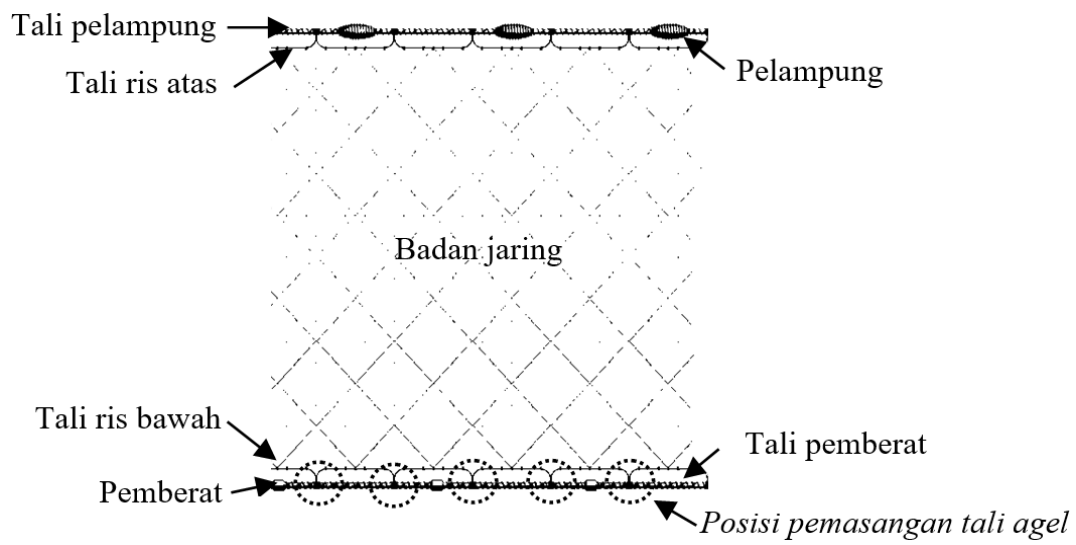

Gambar 13 llustrasi posisi penggunaan tali agel pada gillnet dasar

Tali agel akan rusak dengan periode waktu yang relatif singkat jika dibandingkan benang $P A$, sehingga jaring akan terangkat ke permukaan dan mudah ditemukan untuk dibersihkan. Karena jika dibiarkan terus didasar, jaring tersebut akan terus melakukan operasi penangkapan tanpa kontrol hingga jaring tersebut rusak (IEEP 2005; WAP 2014; NOAA 2015).

Penurunan kekuatan putus tali agel mencapai $50 \%$ dari kekuatan awalnya setelah 28 hari perendaman. Waktu tersebut sangat cukup hingga nelayan melakukan perbaikan dan perawatan terhadap jaringnya. Berdasarkan hasil survey di lapangan, nelayan jaring rajungan biasanya melakukan perbaikan besar pada jaringnya setiap 2-3 minggu sekali. Selebihnya nelayan hanya melakukan perawatan dan perbaikan ringan saja pada beberapa bagian jaring yang ditemukan rusak.

\section{KESIMPULAN}

Tali agel yang tanpa kitosan berwarna coklat terang, kaku dan agak kasar jika diraba. Tali agel berkitosan berwarna coklat tua, tidak begitu kaku, dan lebih halus jika diraba. Kekuatan putus tali agel berkitosan dan tanpa kitosan berbeda nyata secara statistik $(P<0,05)$. Kekuatan putus rata-rata tali agel berkitosan sebesar 24,54 kgf, kekuatan putus tersebut lebih besar dibandingkan dengan tali agel tanpa kitosan yaitu sebesar 15,06 kgf. Kemuluran tali agel yang tidak dilapisi kitosan dan tali yang dilapisi kitosan juga berbeda nyata secara statistik $(P<0,05)$. Rata-rata kemuluran tali agel berkitosan sebesar $18,04 \%$, sedangkan tali agel tanpa kitosan memiliki kemuluran 10,56 \%.

Kekuatan putus tali agel berkurang sebanyak $>50 \%$ setelah dilakukan perendaman selama 28 hari. Walau demikian, kekuatan putus tali agel yang dilapisi kitosan tetap lebih tinggi dibanding tali agel yang tidak dilapisi kitosan. Tali agel berpeluang disisipkan sebagai tali pengikat antara tali ris bawah dan tali pemberat pada alat tangkap jaring rajungan (gillnet).

\section{SARAN}

Perlu dilakukan penelitian lanjutan untuk melihat pengaruh perendaman air terhadap 
kekuatan sifat fisik dan mekanik tali agel pada media air bersirkulasi atau bisa juga langsung direndam dilapangan.

\section{UCAPAN TERIMA KASIH}

Tim peneliti mengucapkan terima kasih kepada Direktorat Jenderal Pendidikan Tinggi yang telah mendukung pendanaan penelitian ini melalui program hibah penelitian dasar untuk bagian.

\section{DAFTAR PUSTAKA}

Antana AE, Pranoto DY, Sulistyono. 2016. Rancang bangun mesin pintal agel. Jurnal $\mathrm{Di}$ namika Kerajinan dan Batik. 33(2): 111120.

[APEC] Asian-Pasific Economic Coopration. 2004. Direlict fishing gear and related marine debris: An educational outreach seminar among APEC Partners. Honolulu: Seminar report, 13-16 January 2004.

Fadhari A. 2015. Study On Strength Broke (Breaking Strength) and Elongation (Elongation) Yarn PA (Polyamide) With Addition Of Skin Stem Extract Salam (Syzygium Polyanthum) With Different Concentration. Jurnal Online Mahasiswa (JOM) Bidang Perikanan dan Kelautan. 2(1): 1-12.

Fox JJ. 1996. Panen Lontar. Jakarta: Pustaka Sinar Harapan.

Gilardi KVK, Carlson-Bremer D, June JA, Antonelis K, Broadhurst G, Cowan T. 2010. Marine spesies mortality in direlict fishing nets in Puger Sound, WA, and the cost/ benefits of direlict net removal. Marine Pollution Bulletin. 60(3): 376-382.

Good TP, June JA, Etnier MA, Broadhurst G. 2010. Direlict fishing nets in Puget Sound and the Northwest Straits: Patterns and threats to marine fauna. Marine Pollution Bulletin. 60(1): 39-50.

Hardjito L. 2006. Aplikasi Kitosan sebagai Bahan Tambahan Makanan dan Pengawet. Prosiding Seminar Nasional Kitin Kitosan. Bogor: Departemen Hasil Perairan. Fakultas Perikanan dan Ilmu Kelautan. Institut Pertanian Bogor. Bogor, 16 Maret 2006.

Herliana P. 2010. Potensi Khitosan sebagai Anti Bakteri Penyebab Periodontitis. Jurnal UI Untuk Bangsa Seri Kesehatan, Sains, dan Teknologi. 1(1): 20-28.
Heyne K. 1987. Tumbuhan Berguna Indonesia. Indonesia: Yayasan Sarana Jaya.

[IEEP] Institute European Environmental Policy. 2005. Ghost Fishing by Lost Fishing Gear. United Kingdom: Poseidon Aquatic Resource Management.

Katili S, Harsunu BT, Irawan S. 2013. Pengaruh Konsentrasi Placticizer Gliserol dan Komposisi Kitosan dalam Zat Pelarut terhadap Sifat Fisik Edibel Film dari Kitosan. Jurnal Teknologi. 6(1): 29-38.

Kumar A, Ashwin KK, Arumugam KP. 2011. Biodegradabel polymers and its aplications. International jurnal of boscience, biochemistry, and bioinformatics. 1(3): 173176.

Liu N, Chen XG, Park HJ, Liu CG, Liu CS, Meng $X H, Y u$ LJ. 2006. Effect of MW and Concentration of Chitosan on Antibacterial Activity of Escherichia coli. Carbohydrate Polymers. 64(1):60-65.

Mainnah M, Diniah, Iskandar BH. 2016. Perpaduan Serat Daun Nanas (Ananas comosus) dan Kitosan sebagai Material Alat Penangkapan Ikan Ramah Lingkungan. Jurnal Marine Fisheries. 7(2): 149-159.

Matjik AA dan Sumertajaya IM. 2000. Perancangan Percobaan (dengan Aplikasi SAS dan MINITAB). Jilid 1. Bogor: IPB Press.

Nisa K. 2005. Karakteristik fluks membran kitosan termodifikasi polyvinil alcohol dengan variasi poluetilena glikol sebagai porogen [skripsi]. Bogor: Fakultas Matematika dan Ilmu Pengetahuan Alam. Institut Pertanian Bogor.

[NOAA] National Oceanic and Athmospheric Administration. 2015. Impact of "Ghost Fishing" via Derelict Fishing Gear. South Carolina: National Ocean Service, National Centers for Coastal Ocean Science, Center for Coastal Environmental Health and Biomolecular Research.

Nofrizal, Ahmad M, Syofyan I, Habibie M. 2012. Kajian Awal Penggunaan Serat Rumput Teki (Fimbristylis sp.), Linggi (Penicum sp.), dan Sianik (Carex sp.) untuk Bahan Alat Penangkapan Ikan. Jurnal Natur Indonesia. 14(1): 100-106.

Prado J, Dremiere PY. 1990. Fishermen's Workbook. Rome: Fishing Technology Service, Fishery Industries Division, Fisheries Departement, FAO.

Qoniurrochmatulloh. 2015. Uji Tarik dan Ketahanan Tali Alat Pelampung Tandan Buah Segar (TBS) Sawit Tipe Jaring. [Skripsi]. 
Bogor: Fakultas Teknologi Pertanian. Institut Pertanian Bogor.

Rachmah FY, Nofrizal, Syofyan I. 2015. Kajian Pemanfaatan Daun Pandan Mengkuang (Pandanus artocapus) sebagai Serat Alami untuk Bahan Alat Penangkapan ikan. Jurnal Online Mahasiswa. 2(2): 1-14.

Rafaat D, Bargen K, Haas A, Sahl HG. 2008. Insights Into The Mode of Action of Chitosan as an Antibacterial Compound. Applied and Environmental Microbiology Journal. 74(12): 3764-3773.

Safitri SR, Yuspardi A, Suardi ML. 2006. Pengaruh Konsentrasi Uba (Adinandra acuminata KORTH) yang Berbeda terhadap Kekuatan Putus dan Kemuluran Benang Tetoron pada Alat Tangkap Payang di Ulak Karang, Kota Padang. Jurnal Mangrove dan Pesisir. 6(1): 1-12.

Selpiana, Patricia, Anggraeni CP. 2016. Pengaruh Penambahan Kitosan dan Gliserol pada Pembuatan Bioplastik dari Ampas Tebu dan Ampas Tahu. Jurnal Teknik Kimia. 22(1): 57-64.

[SNI] Standar Nasional Indonesia ISO 1805: 2010. Alat penangkap ikan berbahan jaring-Penentuan gaya putus dan gaya putus simpul benang jaring. Jakarta: BSN
Sanger G. 2010. Mutu Kesegaran Ikan Tongkol (Auxis tazard) selama Penyimpanan Dingin. Warta IPTEK. 35(1): 39-43.

Suptijah P, Gushagia Y, Sukarsa DR. 2008. Kajian efek daya hambat kitosan terhadap kemunduran mutu fillet ikan patin (Pangasius hypopthalmus) pada penyimpanan suhu ruang. Buletin Teknologi Hasil Perikanan. 11(2): 89-101.

Suptijah P, Jacoeb AM, Rachmania D. 2011. Karakteristik nano kitosan cangkang udang vannamei (Litopenaeus vannamei) dengan metode gelasi ionik. Jurnal $\mathrm{Pe}$ ngolahan Hasil Perikanan Indonesia. 14(2): 78-84.

Tsai GJ, Wu ZY, Su WH. 2000. Antibacterial activity of chitooligosaccharide mixture prepared by cellulose digestion of shrimp chitosan and its application to milk preservation. J Food Protection. 63(6): 747-752.

[WAP] World Animal Protection. 2014. How Ghost Fishing Gear is Endangering Our Sea Life. England: World Society for the Protection of Animals.

Widiastuti, R. 2009. Pengenalan Serat Alam Non Tekstil. Makalah Pada Workshop Kemampuan Layanan Balai. Kerjasama Pusat Kajian Teknologi Departemen Perindustrian dengan Pemda Bangli-Bali di Bangli 3 Maret 2009. 